\title{
DEVELOPMENT AND COMPARISON OF MATHEMATIC MOBILE LEARNING BY USING EXELEARNING 2.0 PROGRAM AND MIT INVENTOR 2
}

\author{
Tri Nova Hasti Yunianta*1, Anissa Putri ${ }^{2}$, Dani Kusuma ${ }^{3}$ \\ ${ }^{1,2,3}$ Universitas Kristen Satya Wacana
}

\section{Article Info \\ Article history: \\ Received Jan 3, 2019 \\ Revised Jan 29, 2019 \\ Accepted Feb 2, 2019}

\section{Keywords:}

Unique Impression

Mathematics Mobile Learning

Exelearning 2.0

MIT Inventor 2

\begin{abstract}
Mathematics mobile learning influences student learning outcomes. Making this application need skills and also the appropriate programs. The first goal in this study is to develop valid and effective mathematics mobile learning. The second goal in this study if using two different programs it would get the same or different results, is it different between the two applications made with different programs? This type of research is research and development (R \& D). The first application research subjects were mathematics teachers and 8th grade students of Junior High School in Salatiga consisted of 28 students and the subjects in this study were divided into two, namely students in the $8 \mathrm{G}$ class who used the mobile learning application and who did not use it and this study was conducted in the second semester academic year 2014/2015. The second application research subject was 10th-grade students of Senior High School in Salatiga, consisted of 24 students. This research was conducted in the second semester of the academic year 2015/2016. The first application development model was using ASSURE Model and developed with ExeLearning program, while the second application used the ADDIE Model and developed with MIT Inventor 2 program. Data on learning outcomes were obtained by giving initial tests and final tests. Data were analyzed using N-gain enhancement test. The mathematics mobile learning application used the ExeLearning 2.0 program to obtain validation results with very good criteria for the display and material sections while for the improvement of student learning outcomes in the high category amounting to 0.7. The second mathematics mobile learning application obtained very good display validation results and for the material section in the good category, while the increase in learning outcomes obtained an increase in the high category which was 0.71 . Both of these applications possessed differences and the characteristics of mobile learning applications also depend on which software is used. It has a unique impression of using the ExeLearning 2.0 application and MIT Inventor 2.
\end{abstract}

Copyright (C) 2019 IKIP Siliwangi. All rights reserved.

\section{Corresponding Author:}

Tri Nova HastiYunianta,

Departement of Mathematics Education,

Universitas Kristen Satya Wacana,

Jl. Diponegoro No 52-60, Salatiga, Jawa Tengah

Email: trinova.yunianta@uksw.edu

\section{How to Cite:}

Yunianta, T. N. H., Putri, A., \& Kusuma, D. (2019). Development and comparison of mathematic mobile learning by using exelearning 2.0 program and MIT inventor 2. Infinity, 8(1), 43-56. 


\section{INTRODUCTION}

Everyone needs to keep learning to deal with the changing times so quickly. Learning can occur anywhere, whether formally held at school or informally outside of school. Robert M. Gagne (Pribadi, 2009) stated that learning is a natural process that leads to changes that we know, what we can do, and how we behave. Slameto (2003) said that learning is a series of physical and mental activities to achieve changes in human behavior due to the interaction of personal experiences related to cognitive, affective, and psychomotor domains. With learning activities, students experience processes and change their abilities from not knowing to know something, on the other hand, learning is the development of new knowledge, skills, or attitudes as people who interact with learning resources (Pribadi, 2009).

Learning resources are all resources used by teachers and students in the learning process in the classroom. This is used as a communication tool, which can interact with students in learning activities and learning processes. Learning media is a tool for delivering learning material. This is also a tool to bring problems and be solved by students (Sudjana \& Rivai, 2013). Miarso (2009) said that learning media is everything that is used to send messages and stimulate students' thoughts, feelings and desires to encourage the learning process.

Optimizing the use of ICT for 21st century learning is very important to be developed especially to create learning media. The 21 st century students live in a boring world of media and spend an average of almost six and a half hours with media and students as multimedia or technology users. Recent studies in the use of ICt in the form of mobile devices are suitable tools especially for improving the quality of education in developing countries (El-Sofany et al, 2014).

Technology that can be used or utilized in education is a variety of computers, laptops, tablets, mobile phones and many more. Tablet is a technology that has a size of 7 10 inches. The next technology is mobile and is the technology that is closest to students and often used by students in everyday life.

Cellphone users in Indonesia always increase every year. In Indonesia currently active mobile users have reached 281.9 million people. This number illustrates that everyone in Indonesia has 1.13 units of cellphones. Along with the development of the word mobile has turned into a smartphone because this application is growing and increasingly sophisticated. Based on the results of surveys and analysis conducted by International Data Corporation in 2009 to 2013 it can be concluded that smartphone users always increase. In 2009 users reached 2.04 million, in 2012 dramatically increased to 13.20 million users and in 2013 became 15.30 million users and students included.

Mobile learning is a mobile device such as a smartphone or tablet PC and also known as a download application and has certain functions so that the function of the mobile device itself. According to Idrus \& Ismail (2010) mobile learning is a learning media that utilizes handphone technology. The concept of application learning brings benefits from the availability of teaching materials that can be accessed at any time and the visualization of interesting material. Motiwalla (2007) found that mobile learning applications (MLA) can be used in class or in distance learning and MLA will never replace classroom learning, but if both are combined, learning can be more effective and flexible.

Mobile learning is a unique type of learning tool to gain access to learning materials, instructions, and questions related to student learning, when and wherever they want to study. Learning can develop by paying attention to learning material, so learning becomes widespread, and can encourage students. motivate for lifelong learning. Mobile 
learning is student learning activities and learning in various places or environments by using technology, especially mobile phones with features and applications. Students can learn wherever they are and provide interesting material so that students don't get bored. This was created to support education in the digital era. Mobile Learning is also considered to be the next step of e Learning by using wireless devices and other communication technologies so that that they can be used in the learning process anytime and anywhere (Ismail \& Idrus, 2009).

Seeing the importance of learning resources and media for students in this digital era, mathematic mobile learning really needs to be developed to be able to help teachers in the teaching and learning process and also to improve their learning outcomes. Developing this mobile learning program has several programs and in this study it will be focused on developing two mathematic mobile learning applications namely exelearning 2.0 and MIT inventor 2. In addition to looking at the validity and effectiveness of the application, it is necessary to look at its uniqueness by examining the comparison of the results of development in order to provide an overview for the researcher who will use both programs. Are the two mathematic mobile learning applications developed valid and effective? How unique is the difference between the two applications.

\section{METHOD}

This research is a type of research and development ( $R \& D$ ) used to produce certain products and test the effectiveness of these products. The product produced in this study was mathematics mobile learning application. This research developed two mobile learning products using different software programs. The first product was mobile learning which was developed using the ExeLearning 2.0 program and the second product was developed using the MIT Inventor 2 program.

The first product research subjects were mathematics teachers and 8th grade students of SMPN 6 Salatiga consisted of 28 students and the subjects in this study were divided into two namely students in class $8 \mathrm{G}$ who used the mobile learning application and those who did not use it. This research was conducted in semester 2 academic year of $2014 / 2015$.

The development of mobile learning application in the first product used the development model of ASSURE. The steps of ASSURE model are as follows: 1). Analysis step (Analyze Learners) where this stage analyzes age, sex, and type of learning style; 2). Determine step (State) where the purpose is to declare learning standards and objectives; 3). Selection step (Select Strategies, Technology, Media, and Materials) where this stage is done to choose strategies, technology, media and materials with the aim of achieving the set standards and learning objectives; 4).Preparation step (Utilize Technology, media and Materials) with activities to prepare technology, media and materials that can support learning activities; 5). Usage step (Require Learner Participation) the activity is to test the product where there are three stages in product testing, namely: expert judgment or expert testing carried out with respondents from media experts or supervisors; Small group test was conducted with small group respondents, namely several students as users of mobile learning applications; and field testing is a trial at school; 6). Evaluation step and revision (Evaluate and Revise) where evaluation is carried out in two ways, namely assessing the learning outcomes of $8 \mathrm{G}$ class students who use the application and who do not use and evaluate mobile learning then if there were improvements, revisions will be made..

The second product research subject was students class X IPS 3.2 SMA Negeri 1 Salatiga totaling 24 students. This research was conducted in the second semester of 
academic year 2015/2016. All these students will use mathematics mobile learning as a learning supplement.

The second product produced in this study was mathematics mobile learning in trigonometry material. The development of this mobile learning application used the ADDIE development model. The development steps are as follows: 1). Analysis where there are three activities at this stage, among others, by analyzing the condition of students both in learning and in the use of technology, especially the use of Android smartphones, analyzing student learning styles thus later the contents of mobile learning can be tailored to user needs and curriculum analysis to find out more in the content of learning which students follow; 2). Design (Mobile Learning Design) where in the design process is a follow-up of the analysis phase by making and developing based on the results of the general analysis of the state of the student, student learning style, curriculum, and material to be taught at the time the research was conducted; 3). Develop (Mobile Learning Development) where this stage is the stage of making mathematic mobile learning after being designed based on student needs including the design of the display aspects and material aspects in it, then this application is tested in two stages: a) expert judgment or expert testing with responsive media experts and material experts; b) small group test with limited respondents, namely with several students as users of mathematic mobile learning.; 4). Implementation (Mobile Learning Implementation) is the stage of applying mathematic learning to the subject of research; 5). Evaluate (Evaluation of Implementation Results) where this stage of evaluation activities includes student learning outcomes after the use of mathematic mobile learning and media effectiveness, as well as student opinions regarding the use of the application.

The data analysis in this study aimed to analyze the student learning style questionnaire, determined the validity of the media, the practicality and effectiveness of the mathematics mobile learning application. In addition, the pretest and posttest questions that will be used were alsoanalyzed for validity thus the questions tested to students were valid questions.

\subsection{Analysis of Student Learning Style}

Data obtained through student learning style questionnaires in qualitative form in the form of letters were converted into quantitative values with the following steps:

1) The type of data taken in the form of qualitative data is then converted into quantitative data with the provisions in Table 1.

Table 1. Scalling Rules

\begin{tabular}{lc}
\hline \multicolumn{1}{c}{ Note } & Score \\
\hline Always (SL) & 5 \\
Frequent (Sr) & 4 \\
Sometimes (Kd) & 3 \\
Rare (Jr) & 2 \\
Never (TP) & 1
\end{tabular}

2) After the data is collected, then calculate the average score of each type of learning style (visual, auditory and kinesthetic) with the formula on the Likert scale as follows.

$$
\mu=\frac{\sum x}{N}
$$


Notes:

$\mu \quad$ : average value

$\sum x \quad:$ total score

$N \quad$ : number of questions in each category of learning styles

3) Based on the average score obtained in each category of learning styles, there are three categories of learning styles namely visual, auditory and kinesthetic and students only have one dominant learning style. Indicators of learning styles are taken from DePorter \& Hernacki (2009). Learning styles can be determined based on the highest average among the three categories of learning styles obtained by students.

\subsection{Analysis of Application Validation Data and Practical Sheets}

Data obtained through the validation sheet of media experts and material experts with scoring tables as shown in Table 2.

Table 2. Scalling Rules

\begin{tabular}{cc}
\hline Note & Score \\
\hline Very Good (SB) & 5 \\
Good (B) & 4 \\
Fair (C) & 3 \\
Less (K) & 2 \\
Very Less (SK) & 1 \\
\hline
\end{tabular}

1) Quantifying the results of checking in accordance with predetermined indicators by giving a score according to a predetermined weight.

2) Make data tabulation.

3) Changing the value of each aspect of the criteria in each component of the mathematics application becomes qualitative with the criteria for the assessment category with the provisions in Table 3.

$$
\text { Assessment Percentage }=\frac{\text { score of research result }}{\text { maximum score }} \times 100 \%
$$

The categories from Table 3 are said to be valid if a minimum is included in the sufficient category.

Table 3. Assessment Criteria

\begin{tabular}{lcc}
\hline No & Interval & Qualitative Category \\
\hline 1 & $85 \% \leq$ score $\leq 100 \%$ & Very Valid \\
2 & $70 \% \leq$ score $\leq 85 \%$ & Valid \\
3 & $50 \% \leq$ score $\leq 70 \%$ & Less Valid \\
4 & $0 \% \leq$ score $\leq 50 \%$ & Not Valid \\
\hline
\end{tabular}




\subsection{Effectiveness of Mobile Learning Application}

The effectiveness of mathematics mobile learning is determined based on posttest learning outcomes and based on the results of student opinion sheets. The results of student opinion sheets are analyzed qualitatively. The data of students' posttest learning outcomes that have been collected are then analyzed for the significance of the increase from the pretest values calculated by the following N-Gain formula.

$$
\text { NGain }=\frac{\text { score of posttest }- \text { score of pretest }}{\text { maximum score }- \text { pretest score }}
$$

$\mathrm{N}$-Gain is the average increase in student grades. The classification of $\mathrm{N}$-Gain category as shown in Table 4.

Table 4. Classification of N-Gain Category

\begin{tabular}{cc}
\hline N-Gain Score & Category \\
\hline$G \geq 0.70$ & High Increase \\
$0.30 \leq \mathrm{G}<0,70$ & Medium Increase \\
$\mathrm{G}<0.30$ & Low Increase \\
\hline
\end{tabular}

Based on these categories, mathematics mobile learning is effectively used if at least included in the high increase.

\subsection{Analysis of Posttest Problems Data}

Before the instrument is used to obtain instrument research data, the instrument in the form of a test question will be tested first to ensure that the instrument is valid for use. Validity is the degree of accuracy between the data that occurs in the object of research with the power that can be reported by the researcher. The question of the pretest and posttest is through the validation stage by the validator.

\section{RESULTS AND DISCUSSION}

\subsection{Results}

\subsubsection{Description of Student Learning Motivation}

The results of the development of the first mobile learning product were developed with exelearning 2.0 software programs. This application provides sufficient material content, there are learning videos about circles, and there are exercises for students by filling in the blanks and some in the form of multiple choices. In this application, students' learning styles are considered auditory, visual and kinesthetic. Student learning styles are shown in Figure 1. The application developed consisted of three parts, material, learning videos and several practices that can be seen in Figure 1. 


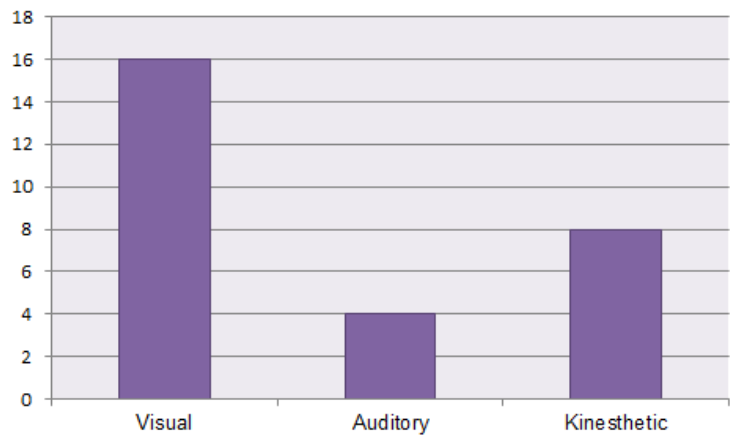

Figure 1. Student Learning Style for Mobile Learning Development with the ExeLearning 2.0 Application

In this class, 28 students participated in the learning process. There were 21 students with smartphones with Android OS and 7 students did not have them.

Circle mobile learning application for 8th grade students of SMP N 6 Salatiga validated by 3 experts. Appraisal validation assessment was seen from two aspects, namely material aspects and also aspects of appearance. This validation assessment sheet consisted of 20 indicators and each aspect consisted of 10 indicators. The results of application validation are in Table 5.

Table 5. Results of Validation of Mobile Learning Application Using the ExeLearning 2.0 Program

\begin{tabular}{lccc}
\hline Aspect & Average & Percentage & Category \\
\hline Material & 44.7 & $89.4 \%$ & Very Valid \\
Display & 42.7 & $85.4 \%$ & Very Valid \\
\hline
\end{tabular}

The menu in this application at the beginning is Menu. In the Menu there are Home, Circles and Evaluations. In the Circle section, there are Circle Elements, Circumference, Area, Central Angle \& Circumference Angle, Length of Bow \& Area of Juring, and Tembereng. Furthermore, in the Evaluation section there are sub-sections namely True False Problem, Multiple Choice Questions and Short Field Questions. The several views in the application can be seen in Figure 2.

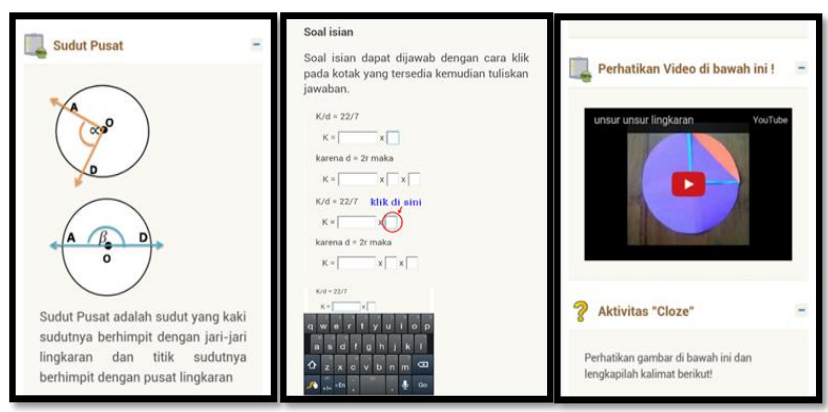

Figure 2. Display of Mobile Learning Application Using ExeLearning

Before students use the application, there is a pretest and after the lesson, there is a posttest held. The material provided is a circle. Student achievements are shown in Table 6. 
Yunianta, Putri, \& Kusuma, Development and comparison of mathematic mobile ...

Table 6. Student Learning Outcomes Using the Mobile Learning Application from the ExeLearning Program

\begin{tabular}{ccccc}
\hline \multirow{2}{*}{ Subject } & \multicolumn{2}{c}{ Average } & Increase & \\
\cline { 2 - 3 } & $\begin{array}{c}\text { Early } \\
\text { Grade }\end{array}$ & $\begin{array}{c}\text { Final } \\
\text { Grade }\end{array}$ & $\begin{array}{c}\text { of } \\
\text { N-Gain }\end{array}$ & Category \\
\hline Using Mobile Learning & 61 & 88.6 & 0.7 & High \\
\hline Not Using Mobile Learning & 71.4 & 82.9 & 0.4 & Medium \\
\hline
\end{tabular}

\subsubsection{Mathematics Mobile Learning Development Product Using the MIT Inventor 2 Program}

The second application was developed using the MIT Inventor 2 program provided online. This application is made for Trigonometry material for mathematics subject. The contents of this mobile learning application include material content, video learning about trigonometric concepts, and student multiple choice questions. In this application also try to be made based on student learning styles. Figure 3 shows students' learning styles in the class used.

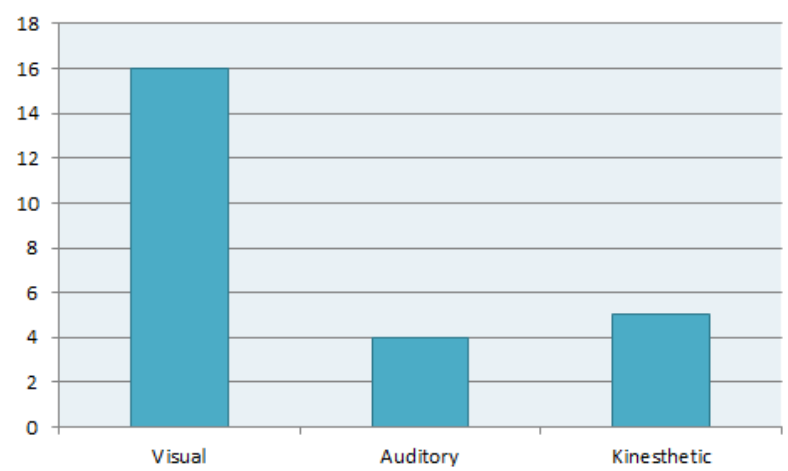

Figure 3. Student Learning Styles for Mobile Learning Development with the MIT Inventor 2 Application

According to data from Figure 3, this application develops more visual parts, and one learning video and 10 practice questions for students. This application is designed with attractive colors to support visual learning styles.

This trigonometry learning application is for high school students in grade 3 or XII and is validated by 4 experts. Appraisal validation assessment was seen from two aspects, namely material aspects and also aspects of appearance. This validation assessment sheet consisted of 20 indicators and each aspect consisted of 10 indicators. The results of application validation are in Table 7.

Table 7. Results of Validation of Mobile Learning Application Using the MIT Inventor 2 Program

\begin{tabular}{lccc}
\hline Aspect & Average & Percentage & Category \\
\hline Material & 43,5 & $87 \%$ & Very Valid \\
Display & 40 & $80 \%$ & Valid \\
\hline
\end{tabular}


The appearance can be shown in Figure 4 for video and Figure 5 for material content and problem practice. In this application only one learning video is available. Practice questions are also limited to 10 questions.

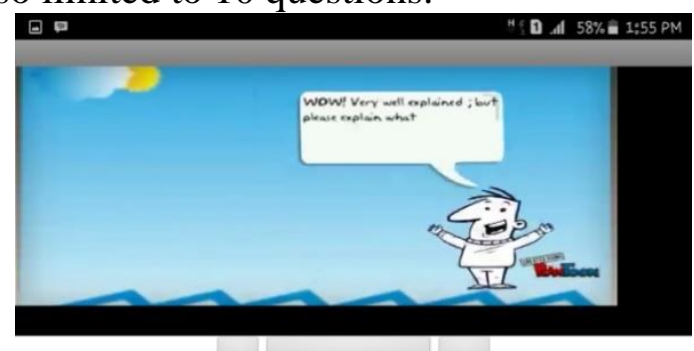

Figure 4. Display of Videos on Mobile Learning Application Using the MIT Inventor Program

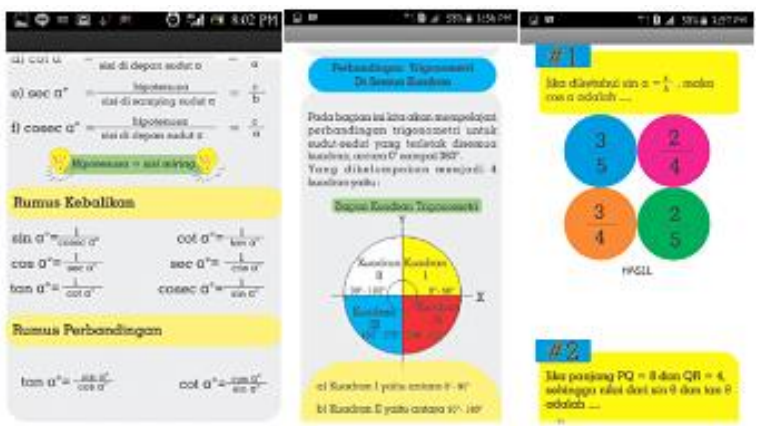

Figure 5. Display of Materials and Questions on Mobile Learning Application Using the MIT Inventor Program

Students who participated in the learning process for the third application were 24 students. All students used this mathematics mobile learning. Student achievements are shown in Table 8.

Table 8. Student Learning Outcomes Using Mobile Learning Application from the ExeLearning Program

\begin{tabular}{ccccc}
\hline \multirow{2}{*}{ Subject } & \multicolumn{2}{c}{ Average } & & \\
\cline { 2 - 3 } & $\begin{array}{c}\text { Early } \\
\text { Grade }\end{array}$ & $\begin{array}{c}\text { Final } \\
\text { Grade }\end{array}$ & Increase & Category \\
\hline $\begin{array}{c}\text { Using Mobile } \\
\text { Learning }\end{array}$ & 53.33 & 86.25 & 0.71 & High \\
\hline
\end{tabular}

The Results should include the rationale or design of the experiments as well as the results of the experiments. Results can be presented in figures, tables, and text. The Results should include the rationale or design of the experiments as well as the results of the experiments. Results can be presented in figures, tables, and text.

\subsection{Discussion}

Before this study there was a study by Karabatzaki et al., (2018) about Mobile learning for preschool where it was stated that children's cognitive skills development with digital media and have well-designed mobile-based learning activities and games could improve skills of abstract thinking, reflective thinking, and analyzing and evaluating 
information planning and scientific reasoning. Other research by Kattayat, Josey, \& Asha (2017) found that the results show that teaching learning processes using mobile apps are helpful to students in improving their learning achievements.

In the first mathematics mobile learning application that was developed using the ExeLearning 2.0 program seen in the results of validation according to Table 5 stated that in display and material, this application met the criteria very well. The ExeLearning 2.0 program allows mobile learning application makers to fill material, images, videos and practice questions easily and varied. The program also provides a variety of practice questions. For example, this application can be filled in with the practice of true false questions, multiple choice questions and short answer questions. The appearance for the application theme is indeed limited, however the choice given is quite a lot, so we make it possible to determine the theme of the application made. The material that is loaded can also vary and easily combine words, images and videos in the application. The programming language used is HTML 5.

Table 9. Differences Between Two Mathematics Mobile Learning Products

\begin{tabular}{|c|c|c|}
\hline $\begin{array}{l}\text { Aspects } \\
\text { Seen }\end{array}$ & $\begin{array}{l}\text { Mathematics Mobile Learning } \\
\text { with ExeLearning 2.0 Program }\end{array}$ & $\begin{array}{l}\text { Mathematics Mobile Learning } \\
\text { with MIT Inventor } 2 \text { Program }\end{array}$ \\
\hline $\begin{array}{l}\text { Learning } \\
\text { Video }\end{array}$ & $\begin{array}{l}\text { There are } 3 \text { Video Learning and } \\
\text { giving Learning Videos in this } \\
\text { application easier to enter, } \\
\text { because it can be directly entered } \\
\text { on the application page or } \\
\text { inserted. }\end{array}$ & $\begin{array}{l}\text { There is one video of learning } \\
\text { and giving Video learning is } \\
\text { not so easy, it needs to have } \\
\text { creativity and requires } \\
\text { expertise in programming logic } \\
\text { to include it. }\end{array}$ \\
\hline Total page & $\begin{array}{l}\text { There are } 13 \text { pages, and the } \\
\text { contents of this page are made } \\
\text { easier because there are choices } \\
\text { of videos, questions, or material } \\
\text { to be included }\end{array}$ & $\begin{array}{l}\text { There are } 10 \text { pages, and the } \\
\text { content of this page combines } \\
\text { more material in the image but } \\
\text { the arrangement is more } \\
\text { complicated when combined } \\
\text { with videos or questions }\end{array}$ \\
\hline Exercises & $\begin{array}{l}\text { The exercises are on } 10 \text { pages } \\
\text { where there are quite a lot of } \\
\text { questions provided by the } \\
\text { software, there are multiple } \\
\text { choices, true and false questions } \\
\text { and short questions }\end{array}$ & $\begin{array}{l}\text { The exercises are only available } \\
\text { on one page with } 10 \text { multiple } \\
\text { choice practice questions and to } \\
\text { make so it should be made to } \\
\text { the programming logic }\end{array}$ \\
\hline Display & $\begin{array}{l}\text { Display arrangement is limited } \\
\text { by the existence of templates on } \\
\text { the software and this requires } \\
\text { creativity in providing images or } \\
\text { videos that are presented and } \\
\text { there are } 34 \text { supporting images }\end{array}$ & $\begin{array}{l}\text { It is possible to display a } \\
\text { creative and extraordinary } \\
\text { display depending on the } \\
\text { creativity of the maker and } \\
\text { there are eight pages that } \\
\text { compose the page }\end{array}$ \\
\hline
\end{tabular}




\begin{tabular}{cll}
\hline $\begin{array}{c}\text { Aspects } \\
\text { Seen }\end{array}$ & $\begin{array}{c}\text { Mathematics Mobile Learning } \\
\text { with ExeLearning 2.0 Program }\end{array}$ & $\begin{array}{l}\text { Mathematics Mobile Learning } \\
\text { with MIT Inventor 2 Program }\end{array}$ \\
\hline Material & $\begin{array}{l}\text { Filling out material is easier } \\
\text { because a page is provided and it } \\
\text { only needs to fill and organize } \\
\text { sentences and images, it requires }\end{array}$ & $\begin{array}{l}\text { Giving material is limited and } \\
\text { capabilities are needed with } \\
\text { logic programming, so to fill in } \\
\text { more material can be made in }\end{array}$ \\
& $\begin{array}{l}\text { HTML 5 programming language } \\
\text { expertise for structuring }\end{array}$ & $\begin{array}{l}\text { the form of images by using } \\
\text { programs such as: correl draw } \\
\text { formulas or mathematical }\end{array}$ \\
& operations & inserted in the page \\
\hline
\end{tabular}

The second mathematics mobile learning application made with the MIT Inventor 2 program is equally good. Even though MIT Inventor 2 can be made very well in appearance according to the creativity of the maker, but there are indeed some things that require a longer process to fill the material. This program does not use programming languages but is designed using programming algorithms with programming logic.

Whether or not to use the program is determined by how experienced people make it. In this application, the material aspect is still inferior to using the ExeLearning 2 program with good criteria as shown in Table 7 . The differences between the two mathematics mobile learning products can be seen in Table 9.

Now you need to see the learning outcomes achieved by students who use it. In the first mobile learning application, it shows that student learning outcomes can increase by $70 \%$ and students who do not use it only increase $40 \%$. This application impacts an increase in the high category based on $\mathrm{N}$-Gain analysis. The second mathematics mobile learning application also has the same impact to improve student learning achievement. This application has an impact on the increase in the high category of student learning outcomes, namely $71 \%$.

Ghozi (2014) made mathematics mobile learning using Java 2 mobile edition and he concluded that the learning process involving mobile learning applications is prospective and feasible to use. Zefriyenni \& Mardhiyah (2017) had the same project to develop this application with Netbean software for the equation of two linear variables. They concluded that the application had tested 7 students and they had all students achieved $100 \%$ success.

Furthermore, student responses in Zefriyenni, \& Mardhiyah (2017) noted that students had a positive response when playing mobile learning for SPLDV material. This also happened in this study for two applications that have been developed. Students claimed that this application is very fun because it is designed with images, colors, videos, evaluation questions and menu displays that are easy to learn and more flexible and simple (Alamsyah, \& Ramantoko, 2012; Sulisworo, Ishafit, \& Firdausy, 2016).

Based on the results of the research, these two applications were valid and effective as wellquite successful in improving student learning outcomes. Nevertheless, there is a major problem with the use of this mathematics mobile learning application. This is not only the limitation of many applications for the mathematics learning process, but also the problem of "is it possible for students to use smartphones in each of their schools or classes?" If you haven't already, this application can only be used while in certain conditions where students are allowed to access this application the more it will be better. 


\section{CONCLUSION}

Each application has a difference when it is developed and still depends on which software is used. It has a unique impression between the first and second applications. Both mathematics mobile learning products do have differences from the results of their development. This is indeed influenced by what program is used, but in use, the most important thing is that the two products developed have the ability to improve students' mathematics learning outcomes on certain high-category material. Therefore, the development of this application is needed further to assist students in learning mathematics.

Recommendations for teachers or researchers who will make mathematic mobile learning in particular by using ExeLearning 2.0 and MIT Office 2 programs, if you want to emphasize the content included and the completeness of the material, you should be able to use ExeLearning 2 program. This program is easier filled with various material, images , videos and learning activity links. But if the teacher or researcher wants to emphasize the interesting aspects of the display, it is recommended to use MIT Inventor 2 program because this program is very possible researchers or makers to create according to their tastes and desires but this program requires skills in logic programming.

\section{ACKNOWLEDGEMENTS}

The author would like to thank all of those participating in this research for their help, particularly Headmaster and students of SMA Negeri 1 Salatiga and SMP Negeri 6 Salatiga.

\section{REFERENCES}

Alamsyah, A., \& Ramantoko, G. (2012). Implementations of m-learning in higher education in Indonesia. In Proceedings of 3rd International Conference on Technology and Operation Management.

Deporter, B., \& Hernacki, M. (2009). Discovery Learning: Membiasakan Belajar Nyaman dan Menyenangkan. Bandung: PT. Mizan Pustaka.

El-Sofany, H. F., El-Seoud, S. A., Alwadani, H. M., \& Alwadani, A. E. (2014). Development of Mobile Educational Services Application to Improve Educational Outcomes using Android Technology. International Journal of Interactive Mobile Technologies (iJIM), 8(2), 4-9.

Ghozi, S. (2014). Pengembangan Materi Mobile learning dalam Pembelajaran Matematika Kelas X SMA Perguruan Cikini Kertas Nusantara Berau. Indonesian Digital Journal of Mathematics and Education, 1(1).

Ismail, I., \& Idrus, R. M. (2009). Development of SMS Mobile Technology for MLearning for Distance Learners. International Journal of Interactive Mobile Technologies, 3(2).

Idrus, R. M., \& Ismail, I. (2010). Role of institutions of higher learning towards a knowledge-based community utilising mobile devices. Procedia-Social and Behavioral Sciences, 2(2), 2766-2770. 
Karabatzaki, Z., Stathopoulou, A., Kokkalia, G., Dimitriou, E., Loukeri, P. I., Drigas, A., \& Economou, A. (2018). Mobile Application Tools for Students in Secondary Education. An Evaluation Study. International Journal of Network \& Mobile Technologies, 12(2).

Kattayat, S., Josey, S., \& Asha, J. V. (2017). Mobile learning apps in instruction and students achievement. International Journal of Interactive Mobile Technologies (iJIM), 11(1), 143-147.

Miarso, Y. (2009). Menyemai Benih Teknologi Pendidikan. Jakarta: Kencana Prenada Media Group.

Motiwalla, L. F. (2007). Mobile learning: A framework and evaluation. Computers \& education, 49(3), 581-596.

Pribadi, B. A. (2009). Model desain sistem pembelajaran. Jakarta: Dian Rakyat.

Slameto (2003). Belajar dan faktor-faktor yang mempengaruhinya. Jakarta: PT Rineka Cipta

Sudjana, N., \& Rivai, A. (2013). Media Pengajaran. Bandung: Sinar Baru Algesindo.

Sulisworo, D., Ishafit, I., \& Firdausy, K. (2016). The Development of Mobile Learning Application using Jigsaw Technique. iJIM, 10(3), 11-16.

Zefriyenni, Z., \& Mardhiyah, H. (2017). Pengembangan mathematics mobile learning application (MMLA)-sistem persamaan linear dua variabel (SPLDV) untuk siswa kelas 8 sebagai sumber pembelajaran mandiri berbasis android. Jurnal Teknologi Informasi dan Pendidikan, 10(2), 25-36. 
